\section{Is Populism Really So Bad for Latin America?}

JOSEPH STIGLITZ was awarded the Nobel Prize for Economics in 2001. He is author, most recently, of Free Trade For All with Andrew Chalton. He spoke with NPQ on Jan. 6.

NPQ | In January, Argentina pre-paid its debt to the International Monetary Fund (IMF) and President Nestor Kirchner said he would no longer negotiate with the IMF because its conditions were too onerous.

Argentina has gotten back on its feet under anti-IMF Kirchner policies. Is Argentina a model for how others should deal with the IMF?

JOSEPH STIGLITZ | In a word, yes. There are two dimensions-the political and the economic. The political dimension has to do with resentment over the intrusion on sovereignty. Whether its advice was good or bad, the arrogant, highhanded way the IMF has interacted with debtor countries has been atrocious, and so it was resented. I've seen close up just how atrocious its "bedside manner" can be.

We have, therefore, seen that, whether they took the IMF advice or not, a string of debtor countries has paid back the IMF as soon as they could. We've seen that with Thailand, Brazil and Korea. Malaysia has steered clear of the IMF completely.

What's interesting in the case of Argentina is that it was willing to pay a price for refusing to deal further with the IMF - the new loans it is getting from Venezuela must be repaid at a higher interest rate than the rate on its IMF loans. Argentina is basically saying the price it was paying for intervention from the IMF was greater than the value of the lower interest rate.

Economically, Argentina has done well because, rightly, it rejected the IMF tight fiscal and monetary policies as dead wrong. They would have driven Argentina into recession or worse, and they favored creditor countries and institutions over Argentina, just as IMF policy in general favors creditors over developing countries.

The IMF bias was totally clear in Argentina. After Argentina had reached an agreement with 75 percent of its creditors on a payback deal, the IMF, amazingly, insisted on a better deal for the 25 percent who held out! As matter of policy, this is just wrongheaded. Nobody would ever agree to a deal if they knew they could hold out and get a better deal.

This was so blatantly pro-creditor that all across the developing world the IMF lost what remaining credibility it had. The message of the IMF was, "Don't bargain, give the creditors what they want."

NPQ Some critics fear that behind anti-IMF sentiment in Argentina and elsewhere in Latin America also lurks the specter of old-fashioned populism and rejection of the economic discipline embodied by the IMF.

Jorge Castañeda, the former Mexican foreign minister, divides Latin America
What's interesting in the case of Argentina is that it was willing to pay a price for refusing to deal further with the IMF- the new loans it is getting from Venezuela must be repaid at a higher interest rate than the rate on its IMF loans. 
If by populism one means worrying about how the bottom two-thirds of the population fares, then populism is not $a$ bad thing.

Two-thirds of Venezuelans were living in poverty under the old system. into the "sensible left" of Brazil and Chile and the "irresponsible left" of Argentina, Venezuela and now Bolivia under Evo Morales. Castañeda fears that the leaders of these latter countries will maintain popularity at all costs by controlling sources of revenue - whether oil, gas or foreign-debt payments. "This left is disastrous," he says. "Its rule will, as in the past, lead to inflation, greater poverty and inequality."

\section{Do you share these worries?}

STIGLITZ | I would put it differently.

If you look at Venezuela's example, it is that by bargaining tough and hard with the oil companies you can get a better deal. Across the world, many developing countries have gotten a rotten deal. The fraction of value of the resources they've been recovering for their people has been relatively low.

Malaysia brought people in to help Malaysians learn how to manage an oil company, but they owned it completely. Now, and the evidence supports it, they get much better value from their resources than if those resources were foreign-owned.

Bolivia has gotten a pretty bad deal on its natural gas. It can do better, as Evo Morales has said he intends to do.

If Argentina had caved into the IMF, it would have gotten a much worse deal in the debt negotiations. If it had hired the IMF as its negotiator, it would have been really screwed. So, what is wrong with bargaining?

Now, if by populism one means worrying about how the bottom two-thirds of the population fares, then populism is not a bad thing. Two-thirds of Venezuelans were living in poverty under the old system. They gained nothing from the old economics. The GNP might have been going up, but they didn't see any of it.

Obviously, it is of concern if these new leaders of the left in Latin America pretend there are no laws of economics. If they say, "I can deliver the goods" without the resources, that is a problem. But the question is whether the IMF strictures are the only ones consistent with good economics. The answer to that is a resounding no. 


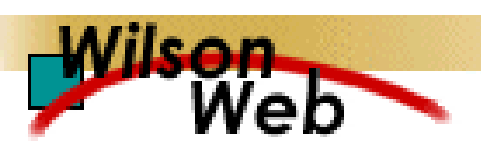

\section{COPYRIGHT INFORMATION}

TITLE: Is Populism Really So Bad for Latin America?

SOURCE: New Perspectives Quarterly 23 no2 Spr 2006

PAGE(S): 61-2

WN: 0610501487020

The magazine publisher is the copyright holder of this article and it is reproduced with permission. Further reproduction of this article in violation of the copyright is prohibited. To contact the publisher: http://www.csdi.org/

Copyright 1982-2006 The H.W. Wilson Company. All rights reserved. 